\title{
Positive association of the hepatic lipase gene polymorphism c.514C > T with estrogen replacement therapy response
}

\author{
Alvaro Pulchinelli $\mathrm{Jr}^{1 *}$, Ana Maria Massad Costa' ${ }^{1}$ Cristina V de Carvalho', Naiara Correa Nogueira de Souza', \\ Mauro A Haidar ${ }^{2}$, Adagmar Andriolo ${ }^{3}$ and Ismael DC Guerreiro da Silva ${ }^{1}$
}

\begin{abstract}
Background: Hepatic lipase $(\mathrm{HL})$, an enzyme present in the hepatic sinusoids, is responsible for the lipolysis of lipoproteins. Human HL contains four polymorphic sites: G-250A, T-710C, A-763G, and C-514T single-nucleotide polymorphism (SNPs). The last polymorphism is the focus of the current study. The genotypes associated with the C514T polymorphism are CC (normal homozygous - W), CT (heterozygous - H), and TT (minor-allele homozygous - M). $\mathrm{HL}$ activity is significantly impaired in individuals of the $\Pi$ and $C T$ genotypes. A total of 58 post-menopausal women were studied. The subjects were hysterectomized women receiving hormone replacement therapy consisting of $0.625 \mathrm{mg}$ of conjugated equine estrogen once a day. The inclusion criteria were menopause of up to three years and normal blood tests, radiographs, cervical-vaginal cytology, and densitometry. DNA was extracted from the buccal and blood cells of all 58 patients using a commercially available kit (GFX ${ }^{\circledR}$ - Amersham-Pharmacia, USA).

Results: Statistically significant reductions in triglycerides ( $t=2.16 ; n=58 ; p=0.03$ ) but not in total cholesterol ( $t$ $=0.14 ; n=58 ; p=0.89$ ) were found after treatment. This group of good responders were carriers of the T allele; the $C T$ and $\Pi$ genotypes were present significantly more frequently than in the group of non-responders $(p=$ 0.02 or $p=0.07$, respectively). However, no significant difference in HDL-C ( $t=0.94 ; n=58 ; p=0.35)$ or $L D L-C(t=$ $-0.83 ; n=58 ; p=0.41$ ) was found in these patients.

Conclusions: The variation in lipid profile associated with the C-514T polymorphism is significant, and the T allele is associated with the best response to ERT.
\end{abstract}

Keywords: Hepatic lipase gene, Menopause, Hormone replacement therapy, Lipid metabolism, SNP

\section{Background}

Hepatic lipase (HL), an enzyme present in the hepatic sinusoids, is responsible for the lipolysis of lipoproteins. Although also expressed in other tissues, over $95 \%$ percent of the total HL activity is found in the liver [1]. As a key enzyme in lipoprotein metabolism, HL hydrolyzes triglycerides (TG), intermediate-density lipoprotein (IDL-C), high-density lipoprotein (HDL-C), and the surface phospholipids and core TG of small very-low-density lipoprotein (VLDL-C) remnants. HL also aids in the binding of lipoproteins to cellular receptors. In vitro

\footnotetext{
* Correspondence: alvaro@alfa.epm.br

'Laboratório de Biologia Molecular, Departamento de Ginecologia, Escola Paulista de Medicina, Universidade Federal de São Paulo, São Paulo, SP, Brasil Full list of author information is available at the end of the article
}

studies have demonstrated that HL facilitates the binding and entrance of chylomicrons, chylomicron remnants, VLDL-cholesterol (VLDL-C), LDL-C $[2,3]$ and HDL cholesterol (HDL-C) [4-6] into a number of different cell types. Fertile females have lower HL activity than males $[7,8]$.

Patients with HL deficiency often present with hypercholesterolemia, hypertriglyceridemia and increased levels of VLDL-C, remnant chylomicrons, IDL-C, TG-rich LDL-C, and HDL-C [9-11]. However, because not all patients with HL deficiency show these metabolic changes, the condition is sometimes confused with other genetic disorders [12].

The human HL gene, a $60 \mathrm{~kb}$ gene with a $1.6 \mathrm{~kb}$ exon, is present on chromosome 15 [13,14]. The gene

\section{C) Biomed Central}


possesses four known polymorphic sites, and these four sites are in complete linkage disequilibrium. The most common polymorphisms are G-250A, T-710C, A-763G and $\mathrm{C}-514 \mathrm{~T}$ [7], and the most common haplotypes are GTAC and ACGT. Because the C-514T polymorphism occurs in the promoter region of the HL gene, it has been suggested that this polymorphism may influence the metabolic activity of the enzyme [15-17] but not influence transcription [18]. Some authors have found that the polymorphisms do not cause phenotypic changes in females, although they have noted a HDL-C difference in men $[18,19]$. Because HL activity may also be controlled by circulating estrogen [16], it is likely that further studies of the HL gene polymorphisms will provide additional genetic information that may be useful in developing more successful hormone replacement therapies [20].

A meta-analysis of 24,000 cases has demonstrated that $\mathrm{HL}$ activity is significantly lower in individuals with the TT and CT genotypes for the C-514T polymorphism than in individuals with the CC genotype [20]. Despite its association with high HDL cholesterol, the presence of the $\mathrm{T}$ allele results in a slightly increased risk of atherosclerosis [7]. Human and animal studies have found both atherogenic and anti-atherogenic activities for the enzyme [21]. While low HL activity is associated with a greater risk of arterial coronary disease (ACD) [22], it is not directly responsible for this disorder [23]. Although there seems to be an inverse relationship between HL level and atherosclerotic disease, a consensus is lacking on this point; some studies have found increased HL in patients with ACD [24]. In humans, increased HL is associated with small, dense LDL-C particles and with lower levels of antiatherogenic large HDL-C particles $[24,25]$. However, studies using animal models have not confirmed this relationship, which suggests that other factors may contribute to the development of ACD. Because HL hydrolyzes phospholipids and triglycerides and releases Fatty Acids (FA) from phospholipids and triglycerides [26], increased HL expression may cause more cholesterol to enter cells and sub-endothelial LDL-C deposits, thus promoting phagocytosis by macrophages and increasing the risk of atherosclerotic lesions. As has been mentioned, HL can have both pro- and anti-atherogenic effects. As an enzymatic or binding protein, it can change the level, composition or metabolism of lipoproteins in ways that can either increase or decrease atherogenesis. In the presence of hypertriglyceridemia and increased LDL-C, high HL activity (the formation of small, dense LDL-C) has a pro-atherogenic effect. However, low levels of LDL-C and high levels of HL may be due to the antiatherogenic effect of increased VLDL-C remnants and IDL-C catabolism [27-29]. The pro- and anti- atherogenic effects of HL may be mediated by the formation of increased levels of small dense LDL-C in the presence of hypertriglyceridemia and by the increased catabolism of VLDL-C remnants and IDL-C, respectively. A number of researchers believe that HL plays an important role in the reverse transport of cholesterol and that its role in this process may be the primary mechanism responsible for the development of atherosclerotic disease [30-34]. There is still great controversy in the literature regarding the pro- and anti-atherogenic roles of HL [32].

Findings that suggest that high HL is responsible for increased atherogenic potential include smaller LDL-C particle size with increased HL activity, enzyme activity that is inversely proportional to HDL-C level, greater activity in males than in fertile females, and a positive correlation of HL level with insulin resistance and/or abdominal fat. Two findings that support an anti-atherogenic role for the enzyme include its reverse cholesterol transport activity and its role in TG clearing after meals [35]. Environmental factors must also be taken into account. There may be a strong interaction effect of HL polymorphisms and the amount and type of dietary fat on HDL-C level [36]. Body mass index (BMI), or adiposity, also appears to affect HL activity, and this effect is additive with the effects of the genetic polymorphisms that have been analyzed [37]. There is also evidence that $\mathrm{HL}$ activity is specifically related to the amount of intraabdominal fat $[17,38]$.

A number of recent studies have failed to support the efficacy of hormone replacement therapy [39-42]. The Heart and Estrogen/Progestin Replacement Study (HERS) conducted by Hulley in 1998 did not recommend the use of HRT for the secondary prevention of arterial coronary disease (ACD); however, due to good ACD outcomes in women taking HRT for several years, HRT continues to be used [39]. A recent study has found that taking estrogen for a mean of 5.9 years was not associated with any change in a woman's ACD risk [43]. Other studies have suggested that hormone replacement therapy may cause pro-thrombotic susceptibility in women with prior atherosclerosis [44].

Estrogen increases plasma levels of apolipoprotein A-1 (ApoA-1) and HDL-C, possibly by increasing ApoA-1 expression in the liver, and it modulates the expression of proteins involved in HDL-C metabolism. Thus, we can expect a high degree of inter-individual variability in HRT response [45]. In rats, estrogen also seems to be associated with the modulation of HL gene expression, and raising HL level decreases HDL-C level [15]. The mechanism by which estrogen reduces LDL-C and increases HDL-C is different from the mechanism of lipid-lowering drugs. This difference may explain why HRT is not effective in preventing the progression of 
coronary heart disease in postmenopausal women $[46,47]$. HL activity is susceptible to variations in endogenous sexual steroids. Estrogenic steroids suppress HL activity, while androgenic steroids increase it $[8,48]$. The effect of the C514T polymorphism on HL activity is independent of androgen action [49].

The current study was motivated by the controversy regarding the pro- and anti-atherosclerotic effects of $\mathrm{HL}$ in women undergoing estrogen replacement therapy. The objective of the study was to optimize hormone replacement therapy by establishing the genetic patterns associated with better responses to such treatment.

\section{Results}

Comparative analysis before and after treatment

The results are presented as the mean and standard deviation of the variables (Table 1 ). Table 1 shows the influence of estrogen replacement treatment on the group as a whole. The values for cholesterol, HDL-C, LDL-C, and triglycerides were analyzed independently of genotype for the both pre- and post-treatment conditions.

All of the genotypes were in Hardy-Weinberg equilibrium (Table 2).

\section{Comparative analysis of different genotypes before and after treatment}

To evaluate whether the baseline values of any of the variables were influenced by genotype, Table 3 presents

Table 1 Comparative analysis of the variables before and after treatment, independent of genotype

\begin{tabular}{|c|c|c|c|c|c|}
\hline Groups & $\mathbf{N}$ & Mean (mg/dL) & Standard deviation & $\mathrm{t}$ & $p$ \\
\hline TotalChol & 58 & 210.31 & 45.47 & 0.14 & 0.89 \\
\hline TotalChol2 & 58 & 209.41 & 43.19 & & \\
\hline HDL-C & 58 & 58.95 & 13.45 & 0.94 & 0.35 \\
\hline HDL-C2 & 58 & 57.76 & 14.44 & & \\
\hline LDL-C & 58 & 120.052 & 38.71 & -0.83 & 0.41 \\
\hline LDL-C2 & 58 & 125.52 & 38.08 & & \\
\hline TG & 58 & 138.07 & 65.40 & 2.16 & 0.03 \\
\hline TG2 & 58 & 122.07 & 66.50 & & \\
\hline \multicolumn{6}{|c|}{$\begin{array}{l}\text { TotalChol: total pre-treatment cholesterol; HDL-C: pre-treatment high-density } \\
\text { lipoprotein cholesterol; LDL-C: pre-treatment low-density lipoprotein } \\
\text { cholesterol; TG: pre-treatment triglycerides; TotalChol2: total post-treatment } \\
\text { cholesterol; HDL-C2: post-treatment high-density lipoprotein cholesterol; LDL- } \\
\text { C2: post-treatment low-density lipoprotein cholesterol; TG2: post-treatment } \\
\text { triglycerides. }\end{array}$} \\
\hline
\end{tabular}

Table 2 Numbers of expected and observed genotypes according to Hardy-Weinberg equilibrium

\begin{tabular}{llllll}
\hline & CC (N) & $\mathbf{C T}(\mathbf{N})$ & $\mathbf{T T}(\mathbf{N})$ & Chi-Square & $\boldsymbol{p}^{*}$ \\
\hline Observed & 15 & 29 & 14 & 0.000005 & 0.998 \\
\hline Expected & 15.00 & 28.99 & 14.00 & & \\
\hline
\end{tabular}

CC (major-allele homozygote); CT (heterozygote); $\Pi$ (minor-allele homozygote)

${ }^{*} p=0,998$

the lipid profiles by genotype (major-allele homozygote, heterozygote, and minor-allele homozygote).

To further study this potential influence, Table 4 compares the means of the variables by genotype (shows the results of testing). For this purpose, we used an ANOVA model and compared the means by group.

We also analyzed the lipid levels before and after ERT; these results are shown according to genotype in Table 5. In this analysis, we studied the influence of the treatment on lipid levels. Table 6 shows the influence of the $\mathrm{T}$ allele on the lipid profile and response to estrogen treatment.

No statistically significant differences in total cholesterol, HDL-C, or LDL-C were found after re-grouping the genotypes into CT and TT (Table 6). Table 6 shows the influence the $\mathrm{T}$ allele on the lipid profile and estrogen treatment.

Table 7 summarizes the data and shows the correlations between the $\mathrm{C}$ and $\mathrm{T}$ alleles and the baseline lipid values. An ANOVA model was used to compare the mean lipoprotein levels in the patients with $\mathrm{C}$ and $\mathrm{T}$ alleles.

Table 8 shows the influence of the $\mathrm{C}$ and $\mathrm{T}$ alleles on the lipoprotein levels of the patients receiving hormone replacement with estrogen. A multivariate ANOVA model was used to compare the means of the patients

Table 3 Influence of genotype on baseline lipid levels

\begin{tabular}{|c|c|c|c|c|c|c|}
\hline Genotype & Variable & $\mathrm{N}$ & Mean & Standard Deviation & t-test & $p$ \\
\hline $\mathrm{CC}$ & TotalChol & 15 & 216.27 & 47.36 & 0.15 & 0.89 \\
\hline $\mathrm{CT}$ & TotalChol & 29 & 205.42 & 44.03 & 0.08 & 0.94 \\
\hline$\pi$ & TotalChol & 14 & 214.07 & 48.65 & 0.03 & 0.98 \\
\hline $\mathrm{CC}$ & $\mathrm{HDL}-\mathrm{C}$ & 15 & 57.87 & 12.56 & 1.31 & 0.21 \\
\hline $\mathrm{CT}$ & $\mathrm{HDL}-\mathrm{C}$ & 29 & 57.17 & 12.18 & 0.21 & 0.84 \\
\hline$\pi$ & $\mathrm{HDL}-\mathrm{C}$ & 14 & 63.78 & 16.44 & 0.36 & 0.72 \\
\hline $\mathrm{CC}$ & LDL-C & 15 & 134.40 & 42.83 & -0.09 & 0.93 \\
\hline $\mathrm{CT}$ & LDL-C & 29 & 118.21 & 31.19 & -0.14 & 0.89 \\
\hline$\pi$ & LDL-C & 14 & 108.50 & 45.96 & -1.26 & 0.23 \\
\hline$C C$ & $\mathrm{TG}$ & 15 & 132.60 & 45.50 & 1.07 & 0.30 \\
\hline$C T$ & TG & 29 & 136.41 & 70.19 & 1.20 & 0.24 \\
\hline$\pi$ & TG & 14 & 147.36 & 76.01 & 1.71 & 0.11 \\
\hline
\end{tabular}

TotalChol: total pre-treatment cholesterol; HDL-C: pre-treatment high-density lipoprotein cholesterol; LDL-C: pre-treatment low-density lipoprotein cholesterol; TG: pre-treatment triglycerides. 
Table 4 An ANOVA model comparing the mean baseline lipid levels by genotype (major-allele homozygote, heterozygote, and minor-allele homozygote)

\begin{tabular}{|c|c|c|c|c|c|c|}
\hline \multicolumn{7}{|c|}{ ANOVA } \\
\hline & & $\begin{array}{l}\text { Sum of } \\
\text { squares }\end{array}$ & df & $\begin{array}{l}\text { Mean } \\
\text { square }\end{array}$ & $F$ & Sig \\
\hline \multirow[t]{3}{*}{ TotalChol } & $\begin{array}{l}\text { Between } \\
\text { Groups }\end{array}$ & 1425.517 & 2 & 712.759 & 0.337 & 0.716 \\
\hline & $\begin{array}{l}\text { Within } \\
\text { Groups }\end{array}$ & 116446.9 & 55 & 2117.216 & & \\
\hline & Total & 117872.4 & 57 & & & \\
\hline \multirow[t]{3}{*}{ HDL-C } & $\begin{array}{l}\text { Between } \\
\text { Groups }\end{array}$ & 436.616 & 2 & 218.308 & 1.216 & 0.304 \\
\hline & $\begin{array}{l}\text { Within } \\
\text { Groups }\end{array}$ & 9874.228 & 55 & 179.531 & & \\
\hline & Total & 10310.845 & 57 & & & \\
\hline \multirow[t]{3}{*}{ LDL-C } & $\begin{array}{l}\text { Between } \\
\text { Groups }\end{array}$ & 5054.986 & 2 & $2,527.493$ & 1.73 & 0.187 \\
\hline & $\begin{array}{l}\text { Within } \\
\text { Groups }\end{array}$ & 80373.859 & 55 & 1461.343 & & \\
\hline & Total & 85428.845 & 57 & & & \\
\hline \multirow[t]{3}{*}{ TG } & $\begin{array}{l}\text { Between } \\
\text { Groups }\end{array}$ & 1735.875 & 2 & 867.938 & 0.197 & 0.822 \\
\hline & $\begin{array}{l}\text { Within } \\
\text { Groups }\end{array}$ & 242037.8 & 55 & 4400.688 & & \\
\hline & Total & 243773.7 & 57 & & & \\
\hline
\end{tabular}

with the $\mathrm{C}$ and $\mathrm{T}$ alleles. We then compared the lipoprotein changes in response to the treatment, according to genotype.

\section{Discussion}

A statistically significant difference in triglyceride level was observed after ERT compared to baseline (Table 1). To examine the efficacy of ERT, we did not differentiate the subjects by genotype. No statistically significant differences in lipoprotein levels were observed. The $\mathrm{p}$ values for lipoprotein levels before and after treatment were $\mathrm{p}=0.89$ and $\mathrm{p}=0.35$ for HDL-C and LDL-C, respectively; in other words, HDL-C and LDL-C levels did not change significantly after treatment. These findings are probably related to the fact that the major substrates of HL are TG and HDL-C rather than LDL-C $[17,26,27]$.

No statistically significant differences in the baseline level of total cholesterol, HDL-C, LDL-C, or triglycerides were observed among patients of different genotypes
Table 5 Results of the paired-samples t-tests (before and after treatment) according to genotype

\begin{tabular}{|c|c|c|c|c|c|c|}
\hline Genotype & $\begin{array}{l}\text { Variable } \\
\text { (mg/dL) }\end{array}$ & $\mathrm{N}$ & Mean & Standard Deviation & t-test & $p$ \\
\hline \multirow[t]{2}{*}{$\mathrm{CC}$} & TotalChol & 15 & 216.27 & 47.36 & 0.15 & 0.89 \\
\hline & TotalChol 2 & 15 & 214.60 & 39.09 & & \\
\hline \multirow[t]{2}{*}{ CT } & TotalChol & 29 & 205.41 & 44.03 & 0.08 & 0.94 \\
\hline & TotalChol 2 & 29 & 204.66 & 39.76 & & \\
\hline \multirow[t]{2}{*}{$\overline{T T}$} & TotalChol & 14 & 214.07 & 48.65 & 0.03 & 0.98 \\
\hline & TotalChol 2 & 14 & 213.71 & 55.03 & & \\
\hline \multirow[t]{2}{*}{ CC } & HDL-C & 15 & 57.87 & 12.56 & 1.31 & 0.21 \\
\hline & HDL-C 2 & 15 & 54.87 & 15.47 & & \\
\hline \multirow[t]{2}{*}{ CT } & $\mathrm{HDL}-\mathrm{C}$ & 29 & 57.17 & 12.18 & 0.21 & 0.84 \\
\hline & HDL-C 2 & 29 & 56.76 & 13.38 & & \\
\hline \multirow[t]{2}{*}{$\pi$} & $\mathrm{HDL}-\mathrm{C}$ & 14 & 63.79 & 16.44 & 0.36 & 0.72 \\
\hline & HDL-C 2 & 14 & 62.93 & 15.16 & & \\
\hline \multirow[t]{2}{*}{$\overline{C C}$} & LDL-C & 15 & 134.40 & 42.83 & -0.09 & 0.93 \\
\hline & LDL-C2 & 15 & 135.40 & 34.27 & & \\
\hline \multirow[t]{2}{*}{$\mathrm{CT}$} & LDL-C & 29 & 118.21 & 31.19 & -0.14 & 0.89 \\
\hline & LDL-C2 & 29 & 19.62 & 38.01 & & \\
\hline \multirow[t]{2}{*}{$\overline{T T}$} & LDL-C & 14 & 108.50 & 45.96 & -1.26 & 0.23 \\
\hline & LDL-C2 & 14 & 127.14 & 42.28 & & \\
\hline \multirow[t]{2}{*}{$\overline{C C}$} & $\mathrm{TG}$ & 15 & 132.60 & 45.50 & 1.07 & 0.30 \\
\hline & TG2 & 15 & 121.13 & 44.02 & & \\
\hline \multirow[t]{2}{*}{ CT } & TG & 29 & 136.41 & 70.19 & 1.20 & 0.24 \\
\hline & $\mathrm{TG} 2$ & 29 & 121.83 & 73.78 & & \\
\hline \multirow[t]{2}{*}{$\overline{\pi T}$} & $\mathrm{TG}$ & 14 & 147.36 & 76.01 & 1.71 & 0.11 \\
\hline & $\mathrm{TG} 2$ & 14 & 123.57 & 74.68 & & \\
\hline
\end{tabular}

TotalChol: total pre-treatment cholesterol; HDL-C: pre-treatment high-density lipoprotein cholesterol; LDL-C: pre-treatment low-density lipoprotein cholesterol; TG: pre-treatment triglycerides; TotalChol2: total post-treatment cholesterol; HDL-C2: post-treatment high-density lipoprotein cholesterol; LDLC2: post-treatment low-density lipoprotein cholesterol; TG2: post-treatment triglycerides; CC: homozygous major-allele genotype; CT: heterozygous genotype; $\Pi$ : homozygous minor-allele genotype.

(Tables 3 and 4). This finding is interesting because the current literature suggests that polymorphisms can directly influence HL activity, as revealed by differences in lipid levels [48]. Recent results are consistent with our findings regarding total cholesterol [18]. Our findings were obtained using an ANOVA model that 
Table 6 Paired-samples t-tests (before and after treatment) for the CT and TT genotypes

\begin{tabular}{|c|c|c|c|c|c|c|c|c|c|}
\hline \multicolumn{2}{|c|}{$(\mathrm{mg} / \mathrm{dL})$} & \multicolumn{5}{|c|}{ Paired differences } & \multirow[t]{3}{*}{$t$} & \multirow[t]{3}{*}{ df } & \multirow[t]{3}{*}{ Sig (2-tailed) } \\
\hline & & \multirow[t]{2}{*}{ Mean } & \multirow[t]{2}{*}{ SD } & \multirow[t]{2}{*}{ Mean Standard Error } & \multicolumn{2}{|c|}{ 95\% Confidence interval } & & & \\
\hline & & & & & Lower & Upper & & & \\
\hline Pair 1 & TotalChol -TotalChol2 & 0.62791 & 50.96685 & 7.77237 & -15.05738 & 16.31319 & 0.081 & 42 & 0.936 \\
\hline Pair 2 & $\mathrm{HDL}-\mathrm{C}-\mathrm{HDL}-\mathrm{C}-\mathrm{C} 2$ & 0.55814 & 9.9506 & 1.51745 & -2.5042 & 3.62048 & 0.368 & 42 & 0.715 \\
\hline Pair 3 & LDL-C - LDL-C2 & 7.02326 & 53.53614 & 8.16419 & -23.49925 & 9.45274 & -0.86 & 42 & 0.395 \\
\hline
\end{tabular}

HDL: pre-treatment high-density lipoprotein; LDL: pre-treatment low-density lipoprotein; VLDL: pre-treatment very-low-density lipoprotein; HDL2: post-treatment high-density lipoprotein; LDL2: post-treatment low-density lipoprotein

compared the baseline means of the three different groups (CC, CT and TT). The $\mathrm{T}$ allele was associated with higher HDL-C in those individuals with a higher proportion of fat in their diets. No significant differences were observed among CC and CT individuals [36]. Because the patients in this study did not follow a specific diet, we believe that potential differences may have been overshadowed by the variation in the patients' dietary habits. This factor may account for the published

Table 7 An ANOVA model comparing the baseline means of the lipid variables between the $C$ and $T$ alleles

\begin{tabular}{|c|c|c|c|c|c|c|}
\hline \multicolumn{7}{|c|}{ ANOVA } \\
\hline & & $\begin{array}{l}\text { Sum of } \\
\text { squares }\end{array}$ & df & $\begin{array}{l}\text { Mean } \\
\text { square }\end{array}$ & $F$ & Sig \\
\hline \multirow[t]{3}{*}{ TotalChol } & $\begin{array}{l}\text { Between } \\
\text { Groups }\end{array}$ & 46.432 & 1 & 46.432 & 0.022 & 0.881 \\
\hline & $\begin{array}{l}\text { Within } \\
\text { Groups }\end{array}$ & 235698.4 & 114 & 2067.53 & & \\
\hline & Total & 235744.8 & 115 & & & \\
\hline \multirow[t]{3}{*}{$\mathrm{HDL}-\mathrm{C}$} & $\begin{array}{l}\text { Between } \\
\text { Groups }\end{array}$ & 243.083 & 1 & 243.083 & 1.36 & 0.246 \\
\hline & $\begin{array}{l}\text { Within } \\
\text { Groups }\end{array}$ & 20378.607 & 114 & 178.76 & & \\
\hline & Total & 20621.69 & 115 & & & \\
\hline \multirow[t]{3}{*}{$\overline{L D L-C}$} & $\begin{array}{l}\text { Between } \\
\text { Groups }\end{array}$ & 4901.112 & 1 & 4901.112 & 3.367 & 0.069 \\
\hline & $\begin{array}{l}\text { Within } \\
\text { Groups }\end{array}$ & 165956.6 & 114 & 1455.759 & & \\
\hline & Total & 170857.7 & 115 & & & \\
\hline \multirow[t]{3}{*}{ TG } & $\begin{array}{l}\text { Between } \\
\text { Groups }\end{array}$ & 1551.263 & 1 & 1551.263 & 0.364 & 0.548 \\
\hline & $\begin{array}{l}\text { Within } \\
\text { Groups }\end{array}$ & 485996.2 & 114 & 4263.124 & & \\
\hline & Total & 487547.4 & 115 & & & \\
\hline
\end{tabular}

data showing associations of the $514 \mathrm{C}>\mathrm{T}$ polymorphism with measures of HDL-C metabolism, depending on the amount and type of fat consumed [36].

When the three genotypes were analyzed separately, no significant changes in the triglycerides following ERT

Table 8 Results of the paired-samples t-tests for lipoproteins before and after treatment, by allele

\begin{tabular}{|c|c|c|c|c|c|c|}
\hline Allele & $\begin{array}{l}\text { Variable } \\
\mathrm{mg} / \mathrm{dL}\end{array}$ & $\mathrm{N}$ & Mean & SD & t-test & $p$ \\
\hline \multirow[t]{2}{*}{$\bar{C}$} & TotalChol & 59 & 210.93 & 45.26 & 0.20 & 0.85 \\
\hline & TotalChol2 & 59 & 209.71 & 39.06 & & \\
\hline \multirow[t]{2}{*}{$\mathrm{T}$} & TotalChol & 57 & 209.67 & 45.68 & 0.08 & 0.93 \\
\hline & TotalChol2 & 57 & 209.11 & 47.08 & & \\
\hline \multirow[t]{2}{*}{$\mathrm{C}$} & $\mathrm{HDL}-\mathrm{C}$ & 59 & 57.53 & 12.16 & 1.37 & 0.18 \\
\hline & HDL-C2 & 59 & 55.80 & 14.24 & & \\
\hline \multirow[t]{2}{*}{$\mathrm{T}$} & $\mathrm{HDL}-\mathrm{C}$ & 57 & 60.42 & 14.52 & 0.50 & 0.62 \\
\hline & $\mathrm{HDL}-\mathrm{C} 2$ & 57 & 59.79 & 14.35 & & \\
\hline \multirow[t]{2}{*}{$\bar{C}$} & LDL-C & 59 & 126.44 & 37.70 & -0.20 & 0.84 \\
\hline & LDL-C2 & 59 & 127.44 & 36.44 & & \\
\hline \multirow[t]{2}{*}{$\bar{T}$} & LDL-C & 57 & 113.44 & 38.62 & -1.39 & 0.17 \\
\hline & LDL-C2 & 57 & 123.32 & 39.58 & & \\
\hline \multirow[t]{2}{*}{ C } & $\mathrm{TG}$ & 59 & 134.47 & 58.15 & 1.85 & 0.07 \\
\hline & $\mathrm{TG} 2$ & 59 & 121.47 & 59.69 & & \\
\hline \multirow[t]{2}{*}{$\mathrm{T}$} & $\mathrm{TG}$ & 57 & 141.79 & 71.95 & 2.46 & 0.02 \\
\hline & $\mathrm{TG} 2$ & 57 & 122.68 & 72.88 & & \\
\hline
\end{tabular}

TotalChol: total pre-treatment cholesterol; HDL-C: pre-treatment high-density lipoprotein cholesterol; LDL-C: pre-treatment low-density lipoprotein cholesterol; TG: pre-treatment triglycerides; TotalChol2: total post-treatment cholesterol; HDL-C2: post-treatment high-density lipoprotein cholesterol; LDLC2: post-treatment low-density lipoprotein cholesterol; TG2: post-treatment triglycerides; CC: homozygous major-allele genotype; CT: heterozygous genotype; $\Pi$ : homozygous minor-allele genotype. 
were observed. Moreover, this reduction was primarily observed in $\mathrm{T}$ allele carriers (Table 5). To explore the hypothesis that the $\mathrm{T}$ allele may have influenced the results, the genotypes were re-classified as either CT or TT. Although a reduction in lipoprotein was observed, it was not statistically significant $(\mathrm{t}=1.889, \mathrm{p}=0.06)$.

The significant decrease in triglycerides observed in the first analysis was seen only in the CT $(\mathrm{t}=1.20 ; \mathrm{p}=$ $0.24)$ and TT ( $t=1.71 ; \mathrm{p}=0.11)$ genotypes. A significant decrease in triglycerides $(\mathrm{t}=3.22 ; \mathrm{p}=0.02)$ in $\mathrm{T}$ carriers was also found when the CT and TT genotypes were grouped together. In contrast, those with the CC genotype did not show a significant decrease in triglycerides after the treatment $(t=1.07 ; \mathrm{p}=0.30)$ [50].

HDL-C and LDL-C did not differ among genotypes either before or after treatment, even after dividing analyzing the CT and TT genotypes separately (Table 6). All of the two-tailed $p$ values associated with these comparisons were greater than 0.05 . There is speculation about the relationships between HDL-C metabolism and HL polymorphisms. However, these polymorphisms result in only minor variations in HDL-C levels [51], which is consistent with our findings.

We next examined the influence of the $\mathrm{C}$ and $\mathrm{T}$ alleles on the baseline values and on the pre- and post-treatment conditions. No statistically significant differences in any of the baseline variables were observed between the patients with the $\mathrm{C}$ allele and those with the $\mathrm{T}$ allele (Tables 6 and 7). This finding suggests that the presence of the $T$ allele (and low hepatic lipase activity) may be associated with a slightly increased risk of atherosclerosis, despite the high HDL cholesterol in individuals with the $\mathrm{T}$ allele.

The $\mathrm{T}$ allele was associated with a significant reduction in triglycerides. Reduced triglycerides after ERT were observed in individuals of both the TT and CT genotypes, but the reduction was more significant in $\mathrm{T}$ than $\mathrm{C}$ alleles. These results are indirectly expressed with respect to genotype; the comparison of the CT and TT patients showed a trend toward a similar level of triglyceride reduction $(t=1.889 ; \mathrm{p}=0.06)$ (Table 8$)$. These findings indicate that the mechanism of HRT differs from that of the typical lipid-lowering drugs; if the mechanism were the same, the treatment would be expected to have a greater effect on those with the $\mathrm{C}$ allele $[7,8,50]$.

The limitation of our study is the relatively small number of patients included. However, a strength of our study is that it is a prospective study of the Brazilian population, comparing the same women before and after HRT to address the question of whether or not lipid levels are associated with the alleles $\mathrm{C}$ or $\mathrm{T}$.

\section{Conclusions}

In conclusion, HRT seems to reduce triglyceride levels regardless of the genotype at the $\mathrm{C}-514 \mathrm{~T}$ polymorphic locus. Although individuals with the $\mathrm{T}$ allele who receive HRT appear to have a positive lipid profile, the antiatherogenic effect of the $\mathrm{T}$ allele is not clear $[52,53]$. However, the $\mathrm{T}$ allele ( $\mathrm{p}$-values $=0.93$ and 0.02 for cholesterol and triglycerides, respectively) does seem to be a better genetic marker for total cholesterol and triglyceride levels than the $C$ allele ( $p$ values $=0.85$ and 0.07 for cholesterol and triglycerides, respectively). According to the literature [47], there is large inter-individual variability in the plasma lipid response to HT. A similar effect was not observed for LDL-C or HDL-C.

\section{Methods}

\section{Subjects}

The study population was derived from a larger study of hormone replacement therapy in postmenopausal women. The larger study included a total of 200 patients from a tertiary outpatient clinic. One hundred of these women had undergone hysterectomy for myomas and were receiving HRT consisting of a single daily dose $(0.625 \mathrm{mg})$ of conjugated equine estrogen The 100 nonhysterectomized women in the study received hormone replacement therapy consisting of a daily combination of $0.625 \mathrm{mg}$ estrogen and $2.5 \mathrm{mg}$ of medroxyprogesterone (estrogen and progestin replacement therapy). Only those patients who received conjugated equine ERT exclusively and who presented lipid profiles within the reference range were enrolled in our study. A total of 58 patients with a mean age of 54 years were selected for DNA extraction and the subsequent study of the C-514T HL gene polymorphism both before and after ERT.

The inclusion criteria included the following: 1) a maximum three-year history of menopause; 2 ) complete chart information with annual blood work (complete blood count with differential, total cholesterol and fractions, triglycerides, urea, creatinine, blood glucose, estradiol, progestin, $\mathrm{FSH}$, and $\mathrm{LH}$ ) that was within the reference range since the onset of menopause; 3 ) a bilateral mammogram with BI-RADS classification 1 or $2 ; 4$ ) abdominal and pelvic ultrasounds with normal findings; 5) cervical-vaginal cytology that was normal by the Bethesda classification; and 6) bone densitometry (patients within one standard deviation of the ageadjusted mean).

Women who did not comply with the proposed hormone replacement therapy were excluded from the study, as were those who did not meet the above criteria.

Information on alcohol use and other lifestyle factors, such as physical activity and dietary saturated fat, was not collected. The patients were not instructed to follow any specific dietary guidelines.

All patients gave free and informed consent to participate, and the project was approved by the Committee of 
Ethics in Research at the Federal University of São Paulo, with the number CEP 1114/08

\section{Methods}

Buccal tissue samples were obtained with a cytobrush. Samples were placed in Falcon tubes with Tris-EDTA buffer and frozen at $-80^{\circ} \mathrm{C}$ for subsequent genomic DNA extraction. Blood samples were obtained before and after ERT using a Vacutainer ${ }^{\circledR}$. The patients were instructed how to prepare for sampling so as to minimize interference from pre-analytical factors. The patients were instructed to fast from 10 to 14 hours, to maintain their usual diet, not to use alcohol within 72 hours prior to the collection and not to perform strenuous exercise on the collection day [54]. Total cholesterol was measured using the oxidase method. HDL-C was measured by the direct method and by a homogenous assay. Triglycerides were measured using an enzymatic colorimetric method (Advia 1650; Bayer ${ }^{\circledR}$, USA). The LDL-C concentration was obtained using Friedwald's formula [55]. The intra-assay coefficients of variability were less than $5 \%$.

DNA of the buccal mucosa was analyzed using a commercially available PCR kit (GFX ${ }^{\circledR}$; Amersham-Pharmacia, USA) according to the manufacturer's instructions. PCR was carried out using primers to detect the $\mathrm{C}-\mathrm{T}$ change, as described by Somekawa et al. [56]. The following primers were used in this study: LipR, 5'TCACTTGGCAAGGGCATCTTTG-3'; and LipF, 5'GGTCGGGGTAGGTGGCTTCCA-3'. The PCR protocol included 35 cycles at $94^{\circ} \mathrm{C}$ for $30 \mathrm{~s}, 55^{\circ} \mathrm{C}$ for $60 \mathrm{~s}$ and $72^{\circ} \mathrm{C}$ for $90 \mathrm{~s}$, after 2 min of denaturation at $95^{\circ} \mathrm{C}$. PCR fragments were digested with $1.5 \mathrm{U}$ of NiaIII restriction enzyme, followed by electrophoresis in a $3 \%$ low-melting agarose gel that was then stained with ethidium bromide. The size of the amplified fragment was $274 \mathrm{bp}$. Fragments of 226 and $48 \mathrm{bp}$ were obtained for allele T, and fragments of $274 \mathrm{bp}$ were obtained for allele $\mathrm{C}$. The genotypes were expressed as CC (majorallele homozygote (W), $274 \mathrm{bp})$, CT (heterozygote $(\mathrm{H})$, 274,226 , and $48 \mathrm{bp}$ ), and TT (minor-allele homozygote (M), 226 and $48 \mathrm{bp}$ ).

\section{Statistical analysis}

Because each individual had more than one set of observations, we used the paired-samples t-test to compare the quantitative data; this test is equivalent to a standard Student's t-test but is specifically designed for related samples. It requires that the data have a normal distribution. Thus, we initially used the Kolmogorov-Smirnov test to verify that the data were normally distributed. The $\mathrm{p}$ value of the non-normality hypothesis was $>0.05$ for all of the variables. The results are presented as mean and standard deviation.
To determine whether genotype influenced the baseline levels of the variables, we used analysis of variance (ANOVA). We compared the average values for the three genotypes in the samples taken before and after treatment with ERT. The variables included age, total cholesterol, HDL-C, LDL-C and TGL. Hardy-Weinberg equilibrium was checked for the entire sample.

\section{Abbreviations}

ACD: arterial coronary disease; ANOVA: analysis of variance; ApoA-1: apolipoprotein A-1; BMI: body mass index; ERT: estrogen replacement therapy; FA: fatty acids; HRT: hormone replacement therapy; HL: hepatic lipase; HDL-C: high-density lipoprotein; IDL-C: intermediate-density lipoprotein; LDL-C: low-density lipoprotein; PCR: polymerase chain reaction; SNP: single-nucleotide polymorphism; TG: triglycerides; VLDL-C: very-lowdensity lipoprotein

\section{Acknowledgements}

This study was partially supported by a grant from the São Paulo Research Aid Foundation [Fundação de Amparo à Pesquisa do Estado de São Paulo (FAPESP)].

AFIP - Associação Fundo de Incentivo à Pesquisa

\section{Author details}

'Laboratório de Biologia Molecular, Departamento de Ginecologia, Escola Paulista de Medicina, Universidade Federal de São Paulo, São Paulo, SP, Brasil. ${ }^{2}$ Setor de Climatério, Departamento de Ginecologia, Escola Paulista de Medicina, Universidade Federal de São Paulo, São Paulo, SP, Brasil. ${ }^{3}$ Setor de Patologia Clínica/Medicina Laboratorial, Departamento de Medicina, Escola Paulista de Medicina, Universidade Federal de São Paulo, São Paulo, SP, Brasil.

\section{Authors' contributions}

APJ: design and conduct of the study, data collection, data analysis, data interpretation and manuscript writing. AMMC: design and conduct of the study, data collection CVC: data interpretation. NNCS: data collection, data analysis and laboratory analysis in molecular biology MAH: data collection, data interpretation. AA: design of the study, data interpretation, manuscript writing. IDCGS: design and conduct of the study, data analysis, data interpretation, manuscript writing. All authors read and approved the final manuscript.

\section{Competing interests}

The authors declare that they have no competing interests.

Received: 7 September 2011 Accepted: 2 November 2011 Published: 2 November 2011

\section{References}

1. Santamarina-Fojo S, Gonzalez-Navarro H, Freeman L, Wagner E, Nong Z: Hepatic lipase, lipoprotein metabolism, and atherogenesis. Arterioscler Thromb Vasc Biol 2004, 24:1750-1754.

2. Shafi S, Brady SE, Bensadoun A, Havel RJ: Role of hepatic lipase in the uptake and processing of chylomicron remnants in rat liver. J Lipid Res 1994, 35:709-720.

3. Krapp A, Ahle S, Kersting S, Hua Y, Kneser K, Nielsen M, Gliemann J, Beisiegel U: Hepatic lipase mediates the uptake of chylomicrons and VLDL into cells via the LDL receptor-related protein (LRP). J Lipid Res 1996, 37:926-936.

4. Marques-Vidal P, Azéma C, Collet X, Vieu C, Chap H, Perret B: Hepatic lipase promotes the uptake of HDL esterified cholesterol by the perfused rat liver: A study using reconstituted HDL particles of defined phospholipid composition. J Lipid Res 1994, 35:373-384.

5. Lambert G, Chase MB, Dugi K, Bensadoun A, Brewer HB Jr, SantamarinaFojo S: Hepatic lipase promotes the selective uptake of high density lipoprotein-cholesteryl esters via the scavenger receptor B1. J Lipid Res 1999, 40:1294-1303. 
6. Diard P, Malewiak M-I, Lagrange D, Griglio S: Hepatic lipase may act as a ligand in the uptake of artificial chylomicron remnant-like particles by isolated rat hepatocytes. Biochem J 1994, 299:899-894.

7. Zambon A, Deeb SS, Pauletto P, Crepaldi G, Brunzell JD: Hepatic lipase: a marker for cardiovascular disease risk and response to therapy. Current Opinion in Lipidology 2003, 14:179-189.

8. Deeb SS, Zambon A, Carr MC, Ayyobi AF, Brunzell JD: Hepatic lipase and dyslipidemia: interactions among genetic variants, obesity, gender, and diet. J Lipid Res 2003, 44:1279-1286.

9. Jansen $H$, Verhoeven AJ, Weeks L, Kastelein JJ, Halley DJ, van den Ouweland A, Jukema JW, Seidell JC, Birkenhäger JC: Common C-to-T substitution at position -480 of the hepatic lipase promoter associated with a lowered lipase activity in coronary artery disease patients. Arterioscler Thromb Vasc Biol 1997, 17:2837-2842.

10. Hegele RA, Little JA, Vezina C, Maguire GF, Tu L, Wolever TS, Jenkins D|J, Connelly PW: Hepatic lipase deficiency: Clinical, biochemical, and molecular genetic characteristics. Arterioscler Thromb 1993, 13:720-728.

11. Breckenridge WC, Little JA, Alaupovic P, Wang CS, Kuksis A, Kakis G, Lindgren F, Gardiner G: Lipoprotein abnormalities associated with a familial deficiency of hepatic lipase. Atherosclerosis 1982, 45:161-179.

12. Ruel IL, Couture P, Gagne C, Deshaies Y, Simard J, Hegele RA, Lamarche B: Characterization of a novel mutation causing hepatic lipase deficiency among French Canadians. J Lipid Res 2003, 44:1508-1514.

13. Datta S, Luo CC, Li WH, VanTuinen P, Ledbetter DH, Brown MA, Chen SH, Liu SW, Chan L: Human hepatic lipase. Cloned cDNA sequence, restriction fragment length polymorphisms, chromosomal localization, and evolutionary relationships with lipoprotein lipase and pancreatic lipase. J Biol Chem 1988, 263:1107-1110.

14. Ameis D, Stahnkel G, Kobayashi J, McLean J, Lee G, Biischerl M, Schotz MC, Will $\mathrm{H}$ : Isolation and characterization of the human hepatic lipase gene. $J$ Biol Chem 1990, 265:6552-6555.

15. Srivastava N, Chowdhury PR, Averna M, Srivastava RA: Estrogen increases hepatic lipase levels in inbred strains of mice: A possible mechanism for estrogendependent lowering of high density lipoprotein. Mol Cell Biochem 2001, 220:87-93.

16. Jansen H, Verhoeven AJ, Sijbrands EJ: Hepatic lipase: a pro- or antiatherogenic protein? J Lipid Res 2002, 43:1352-1362.

17. Deeb SS, Peng R: The C-514T polymorphism in the human hepatic lipase gene promoter diminishes its activity. J Lipid Res 2000, 41:155-158.

18. Isaacs A, Aulchenko YS, Hofman A, Sijbrands EJ, Sayed-Tabatabaei FA, Klungel OH, Maitland-van der Zee AH, Stricker BH, Oostra BA, Witteman JC, van Duijn CM: Epistatic effect of cholesteryl ester transfer protein and hepatic lipase on serum high-density lipoprotein cholesterol levels. J Clin Endocrinol Metab 2007, 92:2680-2687.

19. Guerra R, Wang J, Grundy SM, Cohen JC: A hepatic lipase (LIPC) allele associated with high plasma concentrations of high density lipoprotein cholesterol. Proc Natl Acad Sci USA 1997, 94:4532-4537.

20. Isaacs A, Sayed-Tabatabaei FA, Njajou OT, Witteman JC, van Duijn CM: The -514 C- > T hepatic lipase promoter region polymorphism and plasma lipids: a meta-analysis. J Clin Endocrinol Metab 2004, 89:3858-3863.

21. Santamarina-Fojo S, Haudenschild C, Amar M: The role of hepatic lipase in lipoprotein metabolism and atherosclerosis. Curr Opin Lipidol 1998, 9:211-219.

22. Dugi KA, Brandauer K, Schmidt N, Nau B, Schneider JG, Mentz S, Keiper T, Schaefer JR, Meissner C, Kather H, Bahner ML, Fiehn W, Kreuzer J: Low hepatic lipase activity is a novel risk factor for coronary artery disease. Circulation 2001, 104:3057-3062.

23. Shohet RV, Vega GL, Anwar A, Cigarroa JE, Grundy SM, Cohen JC: Hepatic lipase (LIPC) promoter polymorphism in men with coronary artery disease. Arterioscler Thromb Vasc Biol 1999, 19:1975-1978.

24. Zambon A, Deeb SS, Brown BG, Hokanson JE, Brunzell JD: Common hepatic lipase gene promoter variant determines clinical response to intensive lipid-lowering treatment. Circulation 2001, 103:792-798.

25. Ruel IL, Couture P, Cohn JS, Bensadoun A, Marcil M, Lamarche B: Evidence that hepatic lipase deficiency in humans is not associated with proatherogenic changes in HDL composition and metabolism. J Lipid Res 2004, 45:1528-1537.

26. Yasuda T, Ishida T, Rader DJ: Update on the role of endothelial lipase in high-density lipoprotein metabolism, reverse cholesterol transport, and atherosclerosis. Circ J 2010, 74:2263-2270.
27. Zambon A, Bertocco S, Vitturi N, Polentarutti V, Vianello D, Crepaldi G: Relevance of hepatic lipase to the metabolism of triacylglycerol-rich lipoproteins. Biochem Soc Trans 2003, 31:1070-1074.

28. Saxena U, Klein MG, Vanni TM, Goldberg LI: Lipoprotein lipase increases low density lipoprotein retention by subendothelial cell matrix. J Clin Invest 1992, 89:373-380.

29. Babaev VR, Patel MB, Semenkovich CF, Fazio S, Linton MF: Macrophage lipoprotein lipase promotes foam cell formation and atherosclerosis in low density lipoprotein receptor-deficient mice. J Biol Chem 2000, 275:26293-26299.

30. von Eckardstein A, Nofer JR, Assmann G: High density lipoproteins and arteriosclerosis. Role of cholesterol efflux and reverse cholesterol transport. Arterioscler Thromb Vasc Biol 2001, 21:13-27.

31. von Eckardstein A, Nofer JR, Assmann G: Acceleration of reverse cholesterol transport. Curr Opin Cardiol 2000, 15:348-354.

32. Jansen $\mathrm{H}$ : Hepatic lipase: friend or foe and under what circumstances? Curr Atheroscler Rep 2004, 6:343-347.

33. Hill SA, McQueen MJ: Reverse cholesterol transport-A review of the process and its clinical implications. Clin Biochem 1997, 30:517-525.

34. Annema W, Tietge UJ: Role of hepatic lipase and endothelial lipase in high-density lipoprotein-mediated reverse cholesterol transport. Curr Atheroscler Rep 2011, 13:257-265.

35. Anderson JL, Carlquist JF: Genetic polymorphisms of hepatic lipase and cholesteryl ester transfer protein, intermediate phenotypes, and coronary risk. J Am Coll Cardiol 2003, 41:1990-1993.

36. Ordovas JM, Corella D, Demissie S, Cupples LA, Couture P, Coltell O, Wilson PW, Schaefer EJ, Tucker KL: Dietary fat intake determines the effect of a common polymorphism in the hepatic lipase gene promoter on high-density lipoprotein metabolism: evidence of a strong dose effect in this gene-nutrient interaction in the Framingham study. Circulation 2002, 106:2315-2321

37. Nie L, Wang J, Clark LT, Tang A, Vega GL, Grundy SM, Cohen JC: Body mass index and hepatic lipase gene (LIPC) polymorphism jointly influence postheparin plasma hepatic lipase activity. J Lipid Res 1998, 39:1127-1130.

38. Carr MC, Hokanson JE, Zambon A, Deeb SS, Barrett PH, Purnell JQ, Brunzell JD: The contribution of intraabdominal fat to gender differences in hepatic lipase activity and low/high density lipoprotein heterogeneity. J Clin Endocrinol Metab 2001, 86:2831-2837.

39. Hulley S, Grady D, Bush T, Furberg C, Herrington D, Riggs B, Vittinghoff E: Randomized trial of estrogen plus progestin for secondary prevention of coronary heart disease in postmenopausal women. Heart and Estrogen/ progestin Replacement Study (HERS) Research Group. JAMA 1998, 280:605-613.

40. Herrington DM, Reboussin DM, Brosnihan KB, Sharp PC, Shumaker SA, Snyder TE, Furberg CD, Kowalchuk GJ, Stuckey TD, Rogers WJ, Givens DH, Waters D: Effects of estrogen replacement on the progression of coronary-artery atherosclerosis. N Engl J Med 2000, 343:522-529.

41. Herrington DM, Klein KP: Randomized clinical trials of hormone replacement therapy for treatment or prevention of cardiovascular disease: a review of the findings. Atherosclerosis 2003, 166:203-212.

42. Grodstein F, Stampfer MJ, Manson JE, Colditz GA, Willett WC, Rosner B, Speizer FE, Hennekens $\mathrm{CH}$ : Postmenopausal estrogen and progestin use and the risk of cardiovascular disease. N Eng J Med 1996, 335:453-461.

43. LaCroix AZ, Chlebowski RT, Manson JE, Aragaki AK, Johnson KC, Martin L, Margolis KL, Stefanick ML, Brzyski R, Curb JD, Howard BV, Lewis CE, Wactawski-Wende J, WHI Investigators: Health outcomes after stopping conjugated equine estrogens among postmenopausal women with prior hysterectomy. JAMA 2011, 305:1305-1314

44. Mosca L, Collins P, Herrington DM, Mendelsohn ME, Pasternak RC, Robertson RM, Schenck-Gustafsson K, Smith SC Jr, Taubert KA, Wenger NK, American Heart Association: Hormone replacement and cardiovascular disease: a statement for healthcare professionals from the American Heart Association. Circulation 2001, 104:499-503.

45. Lamon-Fava S, Asztalos BF, Howard TD, Reboussin DM, Horvath KV, Schaefer EJ, Herrington DM: Association of polymorphisms in genes involved in lipoprotein metabolism with plasma concentrations of remnant lipoproteins and $\mathrm{HDL}$ subpopulations before and after hormone therapy in postmenopausal women. Clin Endocrinol (Oxf) 2010, 72:169-175.

46. Mosca L, Benjamin EJ, Berra K, Bezanson JL, Dolor RJ, Lloyd-Jones DM, Newby LK, Piña IL, Roger VL, Shaw LJ, Zhao D, Beckie TM, Bushnell C, 
D'Armiento J, Kris-Etherton PM, Fang J, Ganiats TG, Gomes AS, Gracia CR, Haan CK, Jackson EA, Judelson DR, Kelepouris E, Lavie CJ, Moore A, Nussmeier NA, Ofili E, Oparil S, Ouyang P, Pinn WW, et al: Effectivenessbased guidelines for the prevention of cardiovascular disease in women-2011 update: a guideline from the american heart association. Circulation 2011, 123:1243-1262.

47. Lamon-Fava S, Herringtonb DM, Reboussinc DM, Sherman M, Horvath K Schaefer EJ, Asztalos BF: Changes in remnant and high-density lipoproteins associated with hormone therapy and progression of coronary artery disease in postmenopausal women. Atherosclerosis 2009, 205:325-330.

48. Chamberlain AM, Folsom AR, Schreiner PJ, Boerwinkle E, Ballantyne CM: Low-density lipoprotein and high-density lipoprotein cholesterol levels in relation to genetic polymorphisms and menopausal status: the atherosclerosis risk in communities (ARIC) study. Atherosclerosis 2008, 200:322-328.

49. Vega GL, Gao J, Bersot TP, Mahley RW, Verstraete R, Grundy SM, White A, Cohen JC: The -514 polymorphism in the hepatic lipase gene (LIPC) does not influence androgen mediated stimulation of hepatic lipase activity. $J$ Lipid Res 1998, 39:1520-1524.

50. Zambon A, Deeb SS, Brown BG, Hokanson JE, Brunzell JD: Common hepatic lipase gene promoter variant determines clinical response to intensive lipid-lowering treatment. Circulation 2001, 792-798.

51. Couture P, Otvos JD, Cupples LA, Lahoz C, Wilson PW, Schaefer EJ, Ordovas JM: Association of the C-514T polymorphism in the hepatic lipase gene with variations in lipoprotein subclass profiles: The Framingham Offspring Study. Arterioscler Thromb Vasc Biol 2000, 20:815-822.

52. Yamakawa-Kobayashi K, Somekawa Y, Fujimura M, Tomura S, Arinami T, Hamaguchi H: Relation of the -514CT polymorphism in the hepatic lipase gene to serum HDL and LDL cholesterol levels in postmenopausal women under hormone replacement therapy. Atherosclerosis 2002 162:17-21.

53. Fan $\mathrm{YM}$, Dastidar $\mathrm{P}$, Jokela $\mathrm{H}$, Punnonen $\mathrm{R}$, Lehtimäki T: Hepatic lipase C480t genotype-dependent benefit from long-term hormone replacement therapy for atherosclerosis progression in postmenopausal women. J Clin Endocrinol Metab 2005, 90:3786-92.

54. National Cholesterol Education Program (NCEP) Expert Panel on Detection, Evaluation, Treatment of High Blood Cholesterol in Adults (Adult Treatment Panel III): Third report of the national cholesterol education program expert panel on detection evaluation and, treatment of high blood cholesterol in adults final report. Circulation 2002, 106:3143-3421.

55. Friedewald WT, Levy RI, Fredrickson DS: Estimation of the concentration of low-density lipoprotein cholesterol in plasma, without use of the preparative ultracentrifuge. Clin Chem 1972, 18:499-502.

56. Somekawa Y, Umeki H, Kobayashi K, Tomura S, Aso T, Hamaguchi H: Effects of hormone replacement therapy and hepatic lipase polymorphism on serum lipid profiles in postmenopausal Japanese women. $J$ Clin Endocrinol Metab 2002, 87:4766-4770.

doi:10.1186/1476-511X-10-197

Cite this article as: Pulchinelli et al.: Positive association of the hepatic lipase gene polymorphism c.514C > T with estrogen replacement therapy response. Lipids in Health and Disease 2011 10:197.

\section{Submit your next manuscript to BioMed Central and take full advantage of:}

- Convenient online submission

- Thorough peer review

- No space constraints or color figure charges

- Immediate publication on acceptance

- Inclusion in PubMed, CAS, Scopus and Google Scholar

- Research which is freely available for redistribution

Submit your manuscript at www.biomedcentral.com/submit
Biomed Central 